\begin{abstract}
Iranica
Abstracta Iranica Revue bibliographique pour le domaine irano-aryen

Volume 40-41 | 2019

Comptes rendus des publications de 2017-2018
\end{abstract}

\title{
Adam Benkato. Studies on the Sogdian Epistolary Tradition
}

Antje Wendtland

\section{Q OpenEdition \\ 1 Journals}

\section{Electronic version}

URL: http://journals.openedition.org/abstractairanica/50547

DOI: 10.4000/abstractairanica. 50547

ISBN: 1961-960X

ISSN: 1961-960X

Publisher:

CNRS (UMR 7528 Mondes iraniens et indiens), Éditions de l'IFRI

Electronic reference

Antje Wendtland, "Adam Benkato. Studies on the Sogdian Epistolary Tradition", Abstracta Iranica [Online], Volume 40-41 | 2019, document 5, Online since 30 December 2019, connection on 22 April 2021. URL: http://journals.openedition.org/abstractairanica/50547 ; DOl: https://doi.org/10.4000/ abstractairanica.50547

This text was automatically generated on 22 April 2021.

Tous droits réservés 


\title{
Adam Benkato. Studies on the Sogdian Epistolary Tradition
}

\author{
Antje Wendtland
}

\section{REFERENCES}

Adam Benkato. Studies on the Sogdian Epistolary Tradition. Turnhout: Brepols. 2018, VI+141 p., 43 b/w ill. + 13 colour ill. (Berliner Turfantexte (BTT) 41)

1 The letters in Sogdian language that have been found until today are of quite diverse form and content. The oldest texts, the so-called Ancient Letters from the early $4^{\text {th }}$ century, are private letters, the documents from Mount Mugh, about 400 years younger, mainly contain economical and juridical information, whereas e.g. the Manichaean letters found in Bezeklik, which presumably were written in the beginning of the $11^{\text {th }}$ century, are of highly official nature and display a very elaborate and sophisticated style - none of which are re-edited here. The present edition presents five fragments of official Manichaean correspondences, around 16 private letters, and several drafts, as well as notes are given in transliteration with translation and philological commentary.

2 The author compares the layout of Sogdian letters in general, indentation, addresses, envelops, stamps, and dates. He then analyses the epistolary formulae, the prescript, proem, and body. He then discusses the epistolary formulae, the mostly very short prescript, the proem, for which he compares different greeting formulae, the body, and the prescript. The result of his analysis is presented in seven tables, showing exemplarily the different structures of Sogdian letters. In addition to a glossary of the fragments of this edition a glossary of the texts in Manichaean script edited by Benkato 2016 is annexed. The book gives an excellent insight and systematic overview to the rather heterogeneous examples of extant letters in Sogdian languages.

3 There is an appendix with the edition and study of three old Turkic fragments, two letters and one order, by Simone Christiane Raschmann. 
4 Some small remarks: B. translates $p t s ̌ k w ' n H$, the transitional element, linking the prescript with the proem, as "a letter". As the word for "letter" is $\delta y k H$ and the meaning of $p t s ̌ k w$ 'nH is "(humble) request" I find the translation a little misleading, cf. p. 91, SykH ZY ptškw'nH where he adopts the translation "letter and entreaty" by Bi \& Sims-Williams (2015). $n^{\prime} m$ in 24.8 does not belong to the preceding adjectives but simply means "named", thus $\gamma w \beta c H$ " $\beta r y c H$ n'm t'nm'n s' $r$ is not "praised and blessed in name. To So-and-so" but "to the praised and blessed, named So-and-So" (cf. 24.17, $25 \mathrm{~V}$ 6, 27 R 2).

\section{AUTHORS}

\section{ANTJE WENDTLAND}

Allemagne 